\title{
The Analysis of the Mycobacterium Leprae Resistance Against Ofloxacin After the Rifampicin Ofloxacin Minocycline (ROM) Therapy
}

\author{
Arif Risdianto Karim ${ }^{1}$, Muh Dali Amiruddin ${ }^{1}$, Farida Tabri ${ }^{1}$, R. Satriono ${ }^{2}$, Mochammad Hatta ${ }^{3}$, \\ Marianti Manggau ${ }^{4}$
}

${ }^{1}$ Dermatovenereology Department, Medical Faculty Hasanuddin University, Makassar, Indonesia

${ }^{2}$ Pediatric Department, Medical Faculty Hasanuddin University, Makassar, Indonesia

${ }^{3}$ Microbiology Department, Medical Faculty Hasanuddin University, Makassar, Indonesia

${ }^{4}$ Pharmacy Faculty Hasanuddin University, Makassar, Indonesia

\section{Email address:}

ayiek_abdulkarim@yahoo.com (A. R. Karim), daliamiruddin@yahoo.com (M. D. Amiruddin), farida_tabri@yahoo.com (F. Tabri), hattaram@indosat.net.id (M. Hatta),ikkkfkuh@yahoo.co.id (R. Satriono), mariantimanggau@unhas.ac.id (M. Manggau)

\section{To cite this article:}

Arif Risdianto Karim, Muh. Dali Amiruddin, Farida Tabri, R. Satriono, Mochammad Hatta, Marianti Manggau. The Analysis of the Mycobacterium Leprae Resistance Against Ofloxacin After the Rifampicin Ofloxacin Minocycline (ROM) Therapy. American Journal of Clinical and Experimental Medicine. Vol. 3, No. 4, 2015, pp. 167-171. doi: 10.11648/j.ajcem.20150304.17

\begin{abstract}
Background: This reserach aimed to determine the correlation between the morphology index and IgM anti PGL-1, and the mutations in gyrA genes in order to detect ofloxacin resistance in the patients with multibacillary (MB) leprosy. Methods: This research was conducted in Dr. Wahidin Sudirohusodo General Hospital and its network hospitals in Makassar using the cohort retrospective design. The research sample comprised 21 patients with MB leprosy who had completed the ROM treatment regimens, and whose bacterial index (BI), morphology index (MI), IgM anti PGL-1 antibody, PCR, and sequencing, skin lesion number, and treatment regularity had been examined. Result: The research revealed that all the samples did not undergo any mutations of the gyrA genes which was responsible for the ofloxacin resistance; however, there was a correlation between BI and the IgM anti PGL-1 antibody, and between IgM anti PGL-1 antibody and the number of the skin lesions. Conclusions: There was no samples found to undergo the mutations of gyrA genes, this could be used as the reference to assess the correlation between the morphology index and the IgM anti PGL-1 antibody with the mutations of the gyrA genes.
\end{abstract}

Keywords: gyrA Genes, Morphology Index, IgM Anti PGL-1 Antibody, Ofloxacin Resistance

\section{Introduction}

Leprosy is a chronic infectious disease caused by Mycobacterium leprae (M. leprae). ${ }^{(1)}$ The main goal of leprosy elimination program is to break the chain of transmission, treat and cure, prevent disability and resistance. Multidrug therapy (MDT) program initiated the World Health Organization (WHO) in 1981, was officially issued on leprosy treatment with the drug combination regimen of dapsone, rifampicin and clofazimine, hereinafter known as MDT-WHO regimens. ${ }^{(2)}$ In many studies, have often obtained their drug resistance component in MDT-WHO. Therefore a lot of research to find alternative regimens that more effective, shorter treatment period, with clinical, bacteriology and histopathology improvement. ${ }^{(3)}$
One of alternative regimen for the treatment of leprosy is combination rifampicin ofloxacin minocycline (ROM), which has a high level of compliance because it is not taken daily and a shorter treatment. ${ }^{(4)}$ Ofloxacin resistance in the treatment of leprosy was first reported by Cambau et al in $1997 .{ }^{(5)}$ Although the level of resistance to ofloxacin still low, but it needs to be watched. ${ }^{(4)}$ Ofloxacin resistance in $M$. leprae is known as a result of specific mutations in codons 89 and 91 in the gyrA genes. ${ }^{(4)}$

In addition to diagnosis, bacteriology examination is useful to determine the classification, assess treatment outcomes and suspect drug resistance. Examination that determines the morphology index (MI). At the time of treatment runs, MI 
has faster decreased compared with BI. If an increase of MI, the likelihood of patients do not regularly take the drug or disruption of drug absorption, or there has been a resistance to the drug. ${ }^{(6-8)}$

After receiving treatment, the levels of IgM anti PGL-1 antibody decreased $50 \%$ or more, accompanied by further reduction in the value of $\mathrm{BI}$ and $\mathrm{MI}$. This indicates that the extermination of leprosy was successful. Conversely, if the titer of IgM anti PGL-1 antibody is still high, this means there is still leprosy bacilli surviving. ${ }^{(6,8)}$

Base on the above stated, we conducted this study aims to determine the correlation between MI and the IgM anti PGL1 antibody, and the mutations in gyrA genes in order to detect ofloxacin resistance in multibacillary leprosy.

\section{Materials and Methods}

This was an observational study using the cohort retrospective design. This study was conducted in Dr. Wahidin Sudirohusodo General hospital and its network hospitals in Makassar, starting from January until March 2015. After receiving approval from the ethics committee on human biomedical research, we obtained 21 subjects who met the study criteria included in this study. Inclusion criteria are multibacillary leprosy, aged over 15 years, after therapy with ROM regimens, at the time of review still showed active clinical symptoms of leprosy, and willing to participate in this study by signing an informed consent form.

All subjects who meet the study criteria, performed the sampling includes the history of the regularity of treatment, counting the number of active skin lesions, slit skin smears for bacterial examination, blood for IgM anti PGL-1 with ELISA and biopsy tissue for PCR followed by sequencing. Data analysis was performed using SPSS version 22. Statistical test was performed using Kruskall-Wallis, post-hoc Mann-Whitney and correlation Spearman tests with significance level $\mathrm{p}<0.05$.

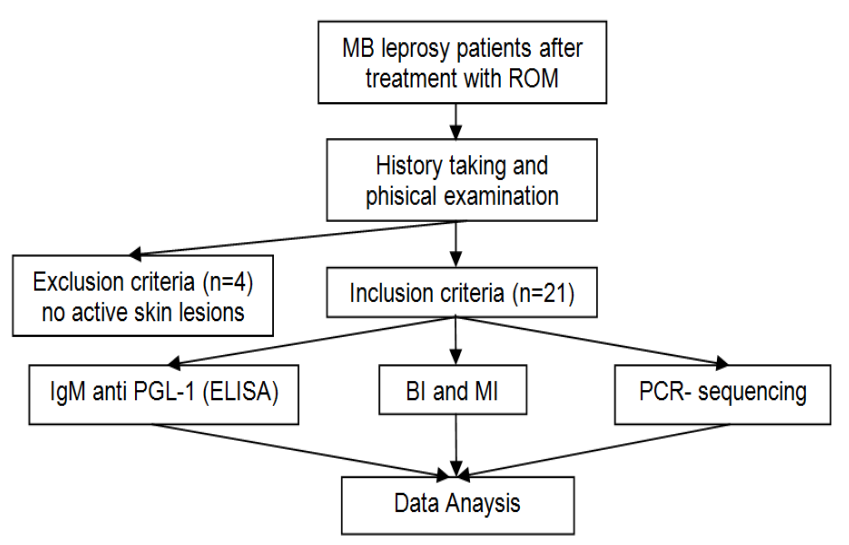

Figure 1. Study flow scheme

\section{Results}

Basic data and comparison obtained respectively - each note and then arranged in tabular form below.
Table 1. Sample characteristics.

\begin{tabular}{|c|c|c|c|}
\hline Sample characteristics & & Frequency & Percent \\
\hline \multirow[t]{5}{*}{ Age } & $16-25$ y.o & 7 & 33.3 \\
\hline & $26-35$ y.o & 5 & 23.8 \\
\hline & $36-45$ y.o & 6 & 28.6 \\
\hline & $46-55$ y.o & 3 & 14.3 \\
\hline & Mean + SD & \multicolumn{2}{|c|}{$33.86+12.171$} \\
\hline \multirow[t]{2}{*}{ Sex } & Man & 12 & 57.1 \\
\hline & Woman & 9 & 42.9 \\
\hline \multirow[t]{3}{*}{ Number of lesion } & 5 & 2 & 9.5 \\
\hline & $6-10$ & 15 & 71.4 \\
\hline & $>10$ & 4 & 19.0 \\
\hline \multirow[t]{2}{*}{ Adherence to medication } & Regular & 20 & 95.2 \\
\hline & Irregular & 1 & 4.8 \\
\hline \multirow[t]{2}{*}{ PCR } & Positive & 0 & 0 \\
\hline & Negative & 21 & 100 \\
\hline \multirow[t]{2}{*}{ gyrA genes mutation } & Positive & 0 & 0 \\
\hline & Negative & 21 & 100 \\
\hline \multirow[t]{3}{*}{ Bacterial Index } & +1 & 7 & 33.3 \\
\hline & +2 & 12 & 57.1 \\
\hline & +3 & 2 & 9.5 \\
\hline \multirow[t]{3}{*}{ Morphology Index } & $0 \%$ & 20 & 95.2 \\
\hline & $0.5 \%$ & 1 & 4.8 \\
\hline & Mean + SD & $0.02+0.109$ & \\
\hline IgM Anti PGL-1 & Mean + SD & $0.27+0.569$ & \\
\hline
\end{tabular}

Note: $\mathrm{PCR}=$ Polymerase chain reaction, $\mathrm{SD}=$ Standard deviations

Table 1 show the characteristics of the sample study that more male patients $(57.1 \%)$, regular therapy $(95.2 \%)$, BI +2 $(57.1 \%)$, MI $0 \%(95.2 \%)$, the number of lesions $6-10$ $(71.4 \%)$, and the mean value of IgM anti PGL-1 is 0.27 OD. In this study we did not find a sample of mutated gyrA genes, so it can not be used as a reference to assess the correlation between the morphology index and IgM anti PGL-1 with the gyrA genes mutation.

The data in Table 2 shows that there is a significant correlation between the bacterial index with the level $\operatorname{IgM}$ anti PGL-1 $(\mathrm{p}<0.05)$.

Table 2. Correlation between the bacterial index with the level IgM anti $P G L-1$.

\begin{tabular}{lllll}
\hline & & Frequency & Mean + SD & $\boldsymbol{p}$ \\
\hline Bacterial Index & +1 & 7 & $0.37+0.071$ & 0.002 \\
& +2 & 12 & $0.28+0.427$ & \\
& +3 & 2 & $0.22+0.015$ & \\
\hline
\end{tabular}

Note: Kruskal-Wallis Test. Post-hoc Mann-Whitney Test: $+1 \mathrm{vs}+2 p=$ $0.002 ;+1 \mathrm{vs}+3 p=0.040 ;+2 \mathrm{vs}+3 p=0.044$

Table 3 shows that there is no significant correlation between the morphology index with the level IgM anti PGL$1(\mathrm{p}>0.05)$ and Table 4 shows that correlation between the morphology index and the gyrA genes mutation can not be done statistical test because there is no gyrA genes mutation .

Table 3. Correlation between the morphology index andthe level IgM anti $P G L-1$.

\begin{tabular}{lll}
\hline & & Morphology Index \\
\hline IgM Anti PGL-1 & $\mathrm{r}$ & 0.370 \\
& $p$ & 0.099 \\
& $\mathrm{n}$ & 21 \\
\hline
\end{tabular}

Spearman correlation test $($ correlation $=$ not significant $)$ 
Table 4. Correlation between the morphology index and the gyrA genes mutation.

\begin{tabular}{lll}
\hline & & Morphology Index \\
\hline \multirow{2}{*}{ gyrA genes mutation } & Positive & 0 \\
& Negative & 0.5 \\
\hline
\end{tabular}

Statistical test can not be done because there is no mutation in gyrA genes

According to the result of the Spearman correlation test in Table 5, we obtain that there is a significant positive correlation between the level of IgM anti PGL-1 and the number of skin lesions. This finding shows that the higher levels of IgM anti PGL-1, the number of skin lesions are more $(\mathrm{p}<0.05)$.

Table 5. Correlation between the level of IgM anti PGL-1 level with the number of skin lesions.

\begin{tabular}{lll}
\hline & & IgM anti PGL-1 \\
\hline Number of lesions & $\mathrm{r}$ & 0.546 \\
& $\mathrm{p}$ & 0.010 \\
& $\mathrm{n}$ & 21 \\
\hline
\end{tabular}

Spearman correlation test

(correlation $=$ significant, direction positive $)$

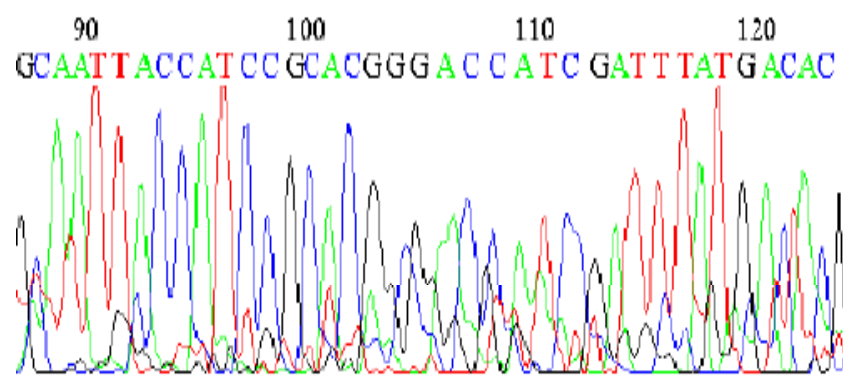

Figure 2. The result from sequencing sample.

\section{Discussion}

This study has been done on the subject of $21 \mathrm{MB}$ type leprosy patients after treatment ROM regimens who is still showing clinical symptoms of active skin lesions obtained the majority of data samples between the ages of 16-25 years. Leprosy is known to occur at any age but in many endemic areas, the peak age is 10-14 years have the disease and the age of 30-50 years. ${ }^{(9)}$ By gender, the highest distribution of male sex (12 cases) than women ( 9 cases). Although leprosy can attack all sexes, but men more suffer than women. In general, after the age of puberty, males than females have a ratio of between 1.5 and $2: 1 .^{(10)}$

The entire sample has the number of skin lesions more than 5 lesions. According to WHO criteria MB leprosy is all type of leprosy with the number of skin lesions 5 or more and slit skin smear positive. ${ }^{(2)}$

A total of $95.2 \%$ of samples showed regularity of taking drugs regimens. Patient adherence to MDT in leprosy treatment is important to minimize the risk of recurrence and avoid the emergence of drug resistance. ${ }^{(11)}$ Research conducted by Haryanto et al have shown a significant correlation between adherence to treatment MDT with laboratory test results. ${ }^{(12)} \mathrm{ROM}$ regimens has a high level of compliance because it is not taken daily regimens and shorter treatment duration ${ }^{(13)}$

Based on morphology index shows only 1 (4.8\%) samples with MI of $0.5 \%$, whereas 20 (95.2\%) samples with MI 0 . In lepromatous leprosy, morphology index fell from a starting point of about $5-20 \%$ to zero after 5-6 months of uninterrupted treatment with dapsone, or after about five weeks of combination therapy regimens using rifampicin. Morphology index climbed back after dropping showed that patients do not regularly take medication or suspected bacilli resistant to the drug regimens. ${ }^{(6)}$ In this study, there is one sample with value of MI $0.5 \%$ because there is a suspicion of resistance to treatment, or there is an error during ZiehlNeelsen staining and examination of acid-fast bacilli due to human error.

The titer IgM anti PGL-1 indicates that the sample has an average value of 0.27 . Conversion IgM anti PGL-1 is considered useful for monitoring the cleaning of the bacterial load, so as to measure the effect of treatment MDT. At lepromatous leprosy are being treated, duration of treatment is an important factor in the development of IgM levels of anti PGL-1, because patients treated for 18 months the level of IgM anti PGL-1 is still positive, whereas patients treated for a long time ( 5 years or more) had antibody levels were normal. Examination of the level of IgM anti PGL-1 is sensitive to all types of MB leprosy cases and only 30-60\% can detect paucibacillary leprosy ${ }^{(14)}$ In this study indicate that there is a significant relationship between the BI after treatment with serological titers IgM anti PGL-1. The study by Lyon et al showed that levels of IgM anti PGL-1 by serology directly related to the bacterial load in patients, perticularly with BI examinations. Patients with high level of BI has the possibility of 19 times higher titers of IgM anti PGL-1 serology. ${ }^{(15)}$

The study also shows that there is a correlation between serological titer IgM anti PGL-1 with the number of skin lesions. This indicates that the greater number of skin lesions appear, the titer of IgM anti PGL-1 higher. Study conducted by De Moura et al showed that the high titers of IgM anti PGL-1 indicates that the bacterial load is also high in patients who are clinically shown by the number of lesions are more numerous and active. Individuals with IgM anti PGL-1 positive had a 7.2 times higher risk of suffering from leprosy when compared with individuals with IgM anti PGL-1 negative. ${ }^{(16)}$

From the results of polymerase chain reaction (PCR) showed as many as 21 samples $(100 \%)$ negative results are found gyrA genes mutation. PCR is a new method for detecting the presence of organisms with specific DNA amplification $^{(1)}$ Further development of this PCR is to study the bacterial resistance to treatment. Positive results indicate the presence of bacteria DNA chain that is specific to the body tissues. ${ }^{(17)}$

Results of M. leprae DNA sequencing samples analyzed 
showed that all $21(100 \%)$ samples did not undergo mutation. DNA sequencing analysis is to look for mutations of certain genes of M. leprae, for example gyrA genes known to encode the formation of an enzyme that is the action target of ofloxacin. If the mutation is obtained, it can be concluded that the enzyme of drugs target has changed, so that the drug became unable to work or in other words the bacillus become resistant to drugs. ${ }^{(17)}$

From this study, there were no gyrA genes mutations that are responsible for drug resistance ofloxacin in all samples of the study. Research on the results of drug resistance frequencies vary in each country, and between the new cases and cases of relapse. In Indonesia, ofloxacin resistance mutation was not found of 121 new cases and 10 cases of relapse were studied. So also is the case in a similar study conducted in Myanmar and Philippines. ${ }^{(18)}$ Research in Vietnam by Kai et al also showed still have not found the mutation in gyrA genes that cause ofloxacin resistance. ${ }^{(19)}$

Ofloxacin resistance in the treatment of leprosy was first reported by Cambau et al in 1997, in a male patient of 35 years with lepromatous leprosy given therapy with rifampin and ofloxacin for 28 days with monitoring, clinical improvement occurs, then the recurrence 1 year later. ${ }^{(5)}$ Ofloxacin resistance in $\mathrm{M}$. leprae is known as a result of specific mutations in codons 89 and 91 in the gyrA genes. Mutations were ever detected in the gyrA genes reported that Ala-Val (GCA-GTA) at codon 91 gyrA genes were confirmed by the Foot Mouse Pad (MFP) and at the Gly-Cys (GGCTGC) at codon 89 gene gyrA but not confirmed by the MFP. ${ }^{(20)}$ Research by Matsuoka et al in cases of relapse and that untreated leprosy in Indonesia, Myanmar and the Philippines indicates that there is no mutation in the gyrA genes. ${ }^{(18)}$ Cambau et al also reported there was only one case of gyrA genes mutation for ofloxacin resistance in leprosy relapse cases that they are long term investigated in France. ${ }^{(21)}$

\section{Abbreviation}

$\mathrm{BI}:$ bacterial index

MB : multibacillary

MDT : multidrug therapy

MFP : mouse foot pads

MI : morphology index

PCR : polymerase chain reaction

ROM : rifampicin ofloxacin minocycline

WHO : World Health Organization

\section{References}

[1] Amiruddin, M.D., Hakim, Z., Darwis, E. Diagnosis Penyakit Kusta. In: Sjamsoe-Daili, E.S., Menaldi, S.L., Ismiarto, S.P., Nilasari, H., eds. Kusta. 2003. Balai Penerbit FKUI: Jakarta.

[2] World Health Organization. Chemotherapy of Leprosy for Control Programmes. Report of a WHO Study Group. WHO Technical Report Series 675. 1982. Wordl Health Organization, Genewa, Switzerland.
[3] Williams, D.L., Spring, L., Harris, E. Dihydropteroate Synthase of Mycobacterium leprae and Dapsone Resistance. Antimicrob Agents Chemother. 2000; 44: 1530-7.

[4] Setia, M.S., Shinde, S.S., Jerajani, H.R., Boivin, J.S. Is There a Role for Rifampicin, Ofloxacin, and Minocycline (ROM) Therapy in the Treatment of Leprosy? Systematic Review and Meta-Analysis. Trop Med \& Intern Health. 2011; 16: 1541-51.

[5] Cambau, E., Perani, E., Guilemin, I., Jamet, P., Ji, B. Multidrug-Resistance to Dapson, Rifampicin, and Ofloxacin in Mycobacterium Leprae. The Lancet. 1997; 349: 103-4.

[6] Bryceson, A. and Pfaltzgraff E.R., eds. Leprosy.1990. Churchill Livingstone: London.

[7] Agusni, I. Imunologi penyakit kusta. In: Sudigdoadi, Sutedja, E., Agusni, I., Sugiri, U., eds. Makalah Lengkap Kursus Imuno-Dermatologi II Dokter Spesialis Kulit dan Kelamin. Bandung: SMF I.K.Kulit \& Kelamin RS Hasan Sadikin. 2000; 231-44.

[8] World Health Organization. 2009. Guidelines for Global Surveillance of Drug Resistance in Leprosy. 2009. World Health Organization: New Delhi.

[9] Noordeen, S. Epidemiology of Leprosy. In: Hastings, R.C. and Opromella, D.V.A., eds. Leprosy. 1994. Churchil Livingstone: New York.

[10] Assiri, A., Yezli, S., Tayeb, T., Almasri, M., Bamgboye, A.E., Memish, Z.A. Eradicating Leprosy in Saudi Arabia: Outcome of a Ten-Year Surveillance (2003-2012). TMAID. 2014; 12: 771-7.

[11] Weiand, D., Thoulass, J., Smith, W.C.S. Assessing and Improving Adherence with Multidrug Therapy. Lepr Rev. 2012; 83: 282-91.

[12] Haryanto, S., Mardini., Pratiwi, Y.S., Pamungkas, I.Y. 2011. Compliance With Type MB Leprosy Patients Post- Treatment Multi Drug Therapy (MDT) With Laboratory Test Results Mycobacterium Leprae In Health Care District Blora. J Ilmu Keperawatan Indonesia. 2011; 1: 1-9.

[13] Villahermosa, L.G., Fajardo, T.T., Abalos, R.M., Cellona, R.V., Balagon, M.V., Cruz, E.C.D., Tan, E.V. Parallel Assasment of 24 Monthly Doses of Rifampicin, Ofloxacin, and Minocycline Versus Two Years of World Health Organization Multi-Drug Therapy for Multi-Bacillary Leprosy. Am J Trop Med Hyg. 2004; 75(2): 197-200.

[14] Zenha, E.M.R., Ferreira, M.A.N., Foss N.T. Use of Anti-PGL1 Antibodies to Monitor Therapy Regimens in Leprosy Patients. 2009; 42: 968-72.

[15] Lyon, S., Silva, S., Lyon, A.C., Grossi, M.A., Azevedo, M.L., Buhrer-Sekula, S., Rocha, M.O. Association of the ML Flow Serological Test with Slit Skin Smear. Revista da Sociedade Brasileira de Med Trop. 2008; 41: 23-6.

[16] De Moura, R.S., Calado, K.L., Oliveira, M.L., Buhrer-Sekula, S. Leprosy Serology Using PGL-1: A Sistemic Review. Revista da Sociedade Brasileira de Med Trop. 2008; 41: 11-8.

[17] Agusni, I., Menaldi, S.L. Beberapa Prosedur Diagnostik Baru pada Penyakit Kusta. In: Sjamsoe-Daili, E.S., Menaldi, S.L., Ismiarto, S.P., Nilasari, H, eds. Kusta. 2003. Balai Penerbit FKUI : Jakarta. 
[18] Matsuoka, M., Budiawan, T., Aye, K.S., Kyaw, K., Tan, E.V., Cruz, E.D., Gelber, R., Saunderson, P., Balagon, V., Pannikar, V. The Frequency of Drug Resistance Mutations in M.Leprae Isolates in Untreated and Relapsed Leprosy Patients from Myanmar, Indonesia and the Philippines. Lepr Rev. 2007; 78: 343-52.

[19] Kai, M., Phuc, N.H.N., Nguyen, H.A., Pham,T.H.B.D., Nguyen, N.H., Miyamoto, Y., et al. Analysis of Drug-Resistant
Strains of Mycobacterium leprae in an Endemic Area of Vietnam. CID. 2011; 52: e127-32.

[20] Matsuoka, M. Drug Resistance in Leprosy. Jpn J Infect Dis. 2010; 63: 1-7.

[21] Cambau, E., Bonnafous, P., Perani, E., Sougakoff, W., Ji, B., Jarlier, V. Molecular Detection of Rifampin and Ofloxacin Resistance for Patients Who Experience Relapse of Multibacillary Leprosy. Clinical Infect Dis. 2002; 34: 39-45. 